\title{
Bringing the Law Back into the History of the Civil Rights Movement
}

\section{Citation}

Kenneth W. Mack, Bringing the Law Back into the History of the Civil Rights Movement, 27 Law \& Hist. Rev. 657 (2009).

\section{Published Version}

http://dx.doi.org/10.1017/S0738248000003941

\section{Permanent link}

http://nrs.harvard.edu/urn-3:HUL.InstRepos:9686135

\section{Terms of Use}

This article was downloaded from Harvard University's DASH repository, and is made available under the terms and conditions applicable to Open Access Policy Articles, as set forth at http:// nrs.harvard.edu/urn-3:HUL.InstRepos:dash.current.terms-of-use\#OAP

\section{Share Your Story}

The Harvard community has made this article openly available.

Please share how this access benefits you. Submit a story.

\section{Accessibility}




\title{
Bringing the Law Back into the History of the Civil Rights Movement
}

\author{
KENNETH W. MACK
}

It is a pleasure to comment on Nancy MacLean's hugely important book Freedom is Not Enough: The Opening of the American Workplace ${ }^{1}$ as an example of what I might call "bringing the law back in" to the history of the civil rights movement. A generation ago, the idea that law needed to be introduced into this history would have seemed nonsensical. At that time, law provided one of the central touchstones in the historical narrative of the struggle for racial equality in American life. Scholarship in this area built on C. Vann Woodward's pioneering work on the rise of Jim Crow, which itself was written shortly after Woodward's participation in the Brown v. Board of Education litigation. ${ }^{2}$ The dominant narrative began with the legal construction of Jim Crow in the late nineteenth century and continued with the founding of the NAACP. Other actors came along at various points in the story, prominent among them New Deal-era racial liberals, World War II-era activists, midcentury social scientists, Southern civil rights leaders and movements, and eventually black power. The end point was marked by the litigation and legislative victories of the 1950s and '60s, which finally wrote back into law what had been taken away by segregationist white Southerners and a compliant Supreme Court in the

1. Nancy MacLean, Freedom is Not Enough: The Opening of the American Workplace (Cambridge: Harvard University Press, 2006).

2. C. Vann Woodward, The Strange Career of Jim Crow, 3rd rev. ed. (New York: Oxford University Press, 1974).

Kenneth W. Mack is a professor of law at Harvard Law School <kmack@law .harvard.edu>. 
late nineteenth century. The implicit methodological take on law was that state and federal statutes, as well as court decisions, provided an important impetus, or at the very least a validation, for racial change-first for white Southerners as they created the Jim Crow legal regime and later for segregation's opponents as they reinscribed racial equality onto the core narrative of American life. ${ }^{3}$

In the last generation, however, this central preoccupation with law has come under attack. In the social history of the civil rights movement, the new model that emerged trained its sights on community-level protest and organization. Its central project was to decenter the NAACP, the Supreme Court, Congress, Martin Luther King, Jr., and the Congress of Racial Equality (CORE) as the central players in the story. Instead, scholars focused on the ways that activists and local actors built up movements and alliances outside the bounds of, or in conflict with, the figures and organizations who once dominated the story. ${ }^{4}$ Of course, there were other new brands of civil rights scholarship, inflected through labor history, international history, and the history of white Northerners and Southerners during the civil rights era. In taking on the old scholarship on its own turf, however, local studies — particularly those of the Southern movement—often set the tone. If there was a methodological take on law in the new histories, it was often that law was epiphenomenal, not that important to local movement actors, and sometimes even corrosive of local community organizing. ${ }^{5}$

3. See, for example, Harvard Sitkoff, The Struggle for Black Equality, 1954-1980 (New York: Farar, Straus and Giroux; Hill and Wang, 1981); Woodward, Strange Career.

4. See, for example, Charles M. Payne, I've Got the Light of Freedom: The Organizing Tradition and the Mississippi Freedom Struggle (1995; Berkeley: University of California Press, 2007); John Dittmer, Local People: The Struggle for Civil Rights in Mississippi (Urbana: University of Illinois Press, 1994). For good summaries of this scholarly shift, see Tomiko Brown-Nagin, "The Impact of Lawyer-Client Disengagement on the NAACP's Campaign to Implement Brown v. Board of Education in Atlanta," in From the Grassroots to the Supreme Court: Brown v. Board of Education and American Democracy, ed. Peter Lau (Durham: Duke University Press, 2004), 227, 228; Payne, I've Got the Light of Freedom, 413-41; Steven Lawson, "Freedom Then, Freedom Now: The Historiography of the Civil Rights Movement," American Historical Review 96 (1991): 456.

5. Payne, I've Got the Light of Freedom, 315; Doug McAdam, Political Process and the Development of Black Insurgency 1930-1970, 2nd ed. (Chicago: University of Chicago Press, 1999), 133-34, 184-85; Aldon D. Morris, The Origins of the Civil Rights Movement: Black Communities Organizing for Change (New York: Free Press, 1984), 35-37. By contrast, many scholars who focus on the Northern civil rights movement, which operated in a region without explicit legal segregation, have explicitly grappled with law as a site of organization and as a means of structuring the choices made by movement actors and their opponents. Thomas J. Sugrue, Sweet Land of Liberty: The Forgotten Struggle for Civil Rights in the North (New York: Random House, 2008); Martha Biondi, To Stand and Fight: The Struggle for Civil Rights in New York City (Cambridge: Harvard University Press, 2003); Robert Self, American Babylon: 
The legal history of the civil rights movement moved in the opposite direction, and focused on the NAACP and the Supreme Court. Institutional histories of the NAACP and biographies of famous civil rights figures dominated the field. In its latest incarnation, this work has diverged completely from the central concerns of historians, and, most notably in the work of Michael Klarman, has focused on the political science-inspired question of whether the Supreme Court, acting alone, can effect social change. ${ }^{6}$

The genius of Nancy's book-aside from its breadth, depth and subtlety-is that it is the first major synthesis to bring law back into the social history of civil rights politics. Nancy comes from the tradition of social history, with its focus on how people remake their political worlds in everyday life. But the centerpiece of her story is Title VII of the Civil Rights Act of 1964 and how ordinary people responded to the bare grant of legal freedom that the statute conferred and found that it was not enough. Beginning in the mid-1960s, these activists and other actors began to remake what Nancy calls the "common sense" of America's ordinary expectations of race, gender, and place in the workforce, and by extension in the larger realm of public life (2). In fact, Freedom is Not Enough could take its place alongside the mainstream 1980s and 1990s legal histories written outside the civil rights context - with its model of law as an arena of struggle in which contending groups and individuals try to put their own stamp on what citizenship means in American life. ${ }^{7}$

Indeed, the story as it emerges here compliments some of the newest work in the legal history of the civil rights movement. For instance, Nancy shows how both NAACP and Legal Defense Fund (LDF) lawyers were key

Race and the Struggle for Postwar Oakland (Princeton: Princeton University Press, 2003); Jeanne Theoharis and Komozi Woodard, Freedom North: Black Freedom Struggles Outside the South, 1940-1980 (New York: Palgrave Macmillan, 2003).

6. Michael J. Klarman, From Jim Crow to Civil Rights: The Supreme Court and the Struggle for Racial Equality (New York: Oxford University Press, 2004); Mark V. Tushnet, Making Civil Rights Law: Thurgood Marshall and the Supreme Court, 1936-1961 (Oxford University Press, 1994); Genna Rae McNeil, Groundwork: Charles Hamilton Houston and the Struggle for Civil Rights (Philadelphia: University of Pennsylvania Press, 1983); Gilbert Ware, William Hastie: Grace Under Pressure (New York: Oxford University Press, 1984). Klarman generalized the argument first put forth in Gerald N. Rosenberg, The Hollow Hope: Can Courts Bring About Social Change? (Chicago: University of Chicago Press, 1991), especially pages 157-69, 336-42. Mark Tushnet's history of the NAACP's desegregation campaign was an important exception, with its grounding of the campaign in its connection to local communities. Mark V. Tushnet, The NAACP's Legal Strategy Against Segregated Education, 1925-1950 (Chapel Hill: University of North Carolina Press, 1987).

7. The most prominent examples of that vein of legal history are the essays collected in the bicentennial issue of the Journal of American History, republished as The Constitution and American Life, ed. David Thelen (Ithaca: Cornell University Press, 1988). 
players in perhaps the most successful of the early movements for racial equality in the workplace - that which focused on desegregating Southern mill workforces (76-90, 108-9). She challenges the common interpretation of the NAACP as a unitary, elite-driven organization caught up in noneconomic rights and the struggle to implement Brown in the South, and which ceded the cutting edge to other groups. Some NAACP and LDF leaders, notably Roy Wilkins and Thurgood Marshall, coexisted uneasily with newer players on the scene as the direct action phase of the movement heated up. Both organizations, however, contained a variety of individuals and institutional frameworks for advancing their agendas, and both found new roles for their advocates and lawyers at the leading edge of reform once Title VII offered them the chance to work with activists and movements on the ground and change the common sense that governed the American workplace. There simply hasn't been enough exploration of the NAACP archives in the years before and after Brown, as the main line of scholarship has followed the familiar school desegregation litigation tracks. ${ }^{8}$

Some of the new work that has done this, notably by Risa Goluboff, David Engstrom, Sophia Lee, and Paul Frymer, has described an NAACP that drove the economic agenda of civil rights in a number of fields and institutions in the post-World War II era. Goluboff has uncovered the organization's labor discrimination litigation of the 1940s which helped redefine just what "civil rights" meant in American legal discourse. Engstrom has found that the NAACP was a leading player in defining the structure and agenda of the state-level FEPCs that proliferated once the drive for a permanent federal FEPC stalled in the late 1940s, and that this agenda yielded legislative proposals that were sometimes innovative even by post-1964 standards. Lee has examined the NAACP's Cold War-era administrative litigation before the National Labor Relations Board that ultimately resulted in a ruling that incorporated a nondiscrimination mandate into unions' duty of fair representation. Frymer has briefly surveyed the NAACP's labor advocacy during the two decades after World War II and has found an organization that mobilized a variety of aggressive strategies in and out of court that, by the $1960 \mathrm{~s}$, began to produce litigation that was far more radical than anything the legislature or executive branch was prepared to entertain. ${ }^{9}$ While Goluboff argues that the labor cases that she chronicles disappeared

8. For an essential corrective to the standard scholarly orientation, see Patricia Sullivan, Lift Every Voice: The NAACP and the Making of the Civil Rights Movement (New York: The New Press, 2009).

9. Risa Goluboff, The Lost Promise of Civil Rights (Cambridge: Harvard University Press, 2007); David Freeman Engstrom, "The Taft Proposal of 1946 and the (Non-) Making of American Fair Employment Law," Green Bag 2d 9 (2006): 181; David Freeman Engstrom, "The Lost Origins of American Fair Employment Law: State Fair Employment Practices 
around 1950, taken together the work of these scholars suggest, as I have argued elsewhere, that there are "reasons to doubt" the standard narrative of a "pervasive, coherent, and stable legal liberalism" emerging by 1950 that replaced the social democratic civil rights politics of the previous decades with a focus on Brown, formal noneconomic rights, and elite visions of civil rights politics. ${ }^{10}$ Nancy takes this story straight through the 1970s, and points to an underemphasized aspect of this process: civil rights advocates changed everyday understandings of ordinary Americans about who belongs in what jobs, producing a ripple effect that continues to transform the nation's workforces and its public life.

Nancy's book also nicely compliments current work in legal history in showing how labor market regulation was key to the attack that civil rights activists launched against racial exclusion in the mill and construction industries in the aftermath of Title VII. Government contracts are a crucial factor in her story and provided the lever that allowed activists to hold a potential club over the heads of both private employers and unions-and just as importantly, to offer an ideological justification for that position that fit comfortably within the tenets of post-New Deal liberal politics (82, 95-96). Indeed, she takes forward the story that has been mapped out in the work of scholars such Willie Forbath, Risa Goluboff, and myself, who have argued that New Deal-era labor market regulation and government contracts provided the opening wedge that allowed civil rights progressives to begin to describe and attack race discrimination in private life. ${ }^{11}$

Bureaus and the Politics of Regulatory Design, 1943-1964" (PhD. diss., Yale University, 2006), 24-264; Sophia Z. Lee, "Hotspots in a Cold War: The NAACP's Postwar Workplace Constitutionalism, 1948-1964," Law and History Review 26 (2008): 327; Paul Frymer, Black and Blue: African Americans, the Labor Movement, and the Decline of the Democratic Party (Princeton: Princeton University Press, 2008).

10. Kenneth W. Mack, "Rethinking Civil Rights Lawyering and Politics in the Era before Brown, Yale Law Journal 115 (2005): 256, 353. Of course, one can debate the economic and political consequences of the NAACP's workplace advocacy, as do both Judith Stein and Paul Frymer in asserting that the civil rights bar's creative advocacy was channeled by the structure of the political and legal system into channels that blunted its radical potential. Stein argues that Title VII litigation was conducted within a narrow framework that contributed to the decline of the industrial workforce. Frymer is far more admiring of the radicalism of the civil rights lawyers' efforts, but argues that those efforts, guided by existing state structures, drove a wedge between the civil rights movement and organized labor. Judith Stein, Running Steel, Running America: Race, Economic Policy, and the Decline of Liberalism (Chapel Hill: University of North Carolina Press, 1998), 69-91; Frymer, Black and Blue, 44-97.

11. William Forbath, "Caste, Class, and Equal Citizenship," Michigan Law Review 98 (1999): 1; Goluboff, Lost Promise of Civil Rights, 81-110; Mack, "Rethinking Civil Rights Lawyering and Politics," 331-42; Kenneth W. Mack, "Law and Mass Politics in the Making of the Civil Rights Lawyer, 1931-1941," Journal of American History 93 (2006): 37, 62. 
Perhaps the most important of these progressives was Charles Houston who, shortly before his untimely death in 1950, offered a vision of New Deal-era regulation of economic life as a basis for attacking race discrimination by private actors in a wide swath of industry. Houston emerged as perhaps the dominant player in shaping the approach of liberal organizations to the emerging state-level FEPC regime. ${ }^{12}$ His unfinished work gives us much to consider as we contemplate the federal government taking a financial stake in large sectors of the twenty-first-century economy, and as we consider the new racial politics that may attach to the nation's first African American president.

Finally, Nancy's book is important for its amazingly broad scope. Taking in African Americans, Mexican Americans, women's rights reformers, Jewish activists, and political conservatives in one book shows one way to move beyond what historians such as Scott Kurashige have called the "binary logic" of race relations history, and to cover more ground than would ordinarily seem possible to do in one monograph. ${ }^{13}$

I'd like to use the remainder of my space to return to methodological questions raised by the fact that Nancy is a social historian, and to offer some thoughts on how a legal historian might react to the book. To make my own methodological commitments clear, I come from the Legal Realist tradition, and thus tend to focus my efforts on the gaps, conflicts, and ambiguities in formal law, and on the legal contours of social life outside formal institutions of law. I'd like to suggest that a realist perspective may have something to contribute to Nancy's pathbreaking work. ${ }^{14}$

The framing device encompassed in Freedom is Not Enough is actually a formalist, rather than a realist one. The book is framed by Lyndon Johnson's famous 1965 speech at Howard University, where the President told Americans bluntly that the recent civil rights legislation had forced them to face up to the proposition that "freedom is not enough" to guaranty true racial equality. Johnson told his mostly black listeners, as well as the nation, that Title VII and its accompanying legislation merely granted formal equality - freedom from facially exclusionary practices - to members of previously subordinated racial groups $(5,73-74)$. Nancy's book picks up on this interpretation to argue that the issue of substantive equality-the actual

12. Mack, "Rethinking Civil Rights Lawyering and Politics," 344-45; David Freeman Engstrom, "The Lost Origins of American Fair Employment Law: Regulatory Choice and the Making of Modern Civil Rights, 1943-1964" (unpublished paper, 2009), 63 \& n. 277.

13. Scott Kurashige, The Shifting Grounds of Race: Black and Japanese Americans in the Making of Multiethnic Los Angeles (Princeton: Princeton University Press, 2008), 6.

14. The exact definitions of Legal Realism and formalism remain hotly contested to this day. My description of realism is strongly influenced by the big-tent definition offered in William W. Fisher III, Morton J. Horwitz, and Thomas Reed, eds., American Legal Realism (New York: Oxford University Press, 1993), xi-xv. 
guaranty of inclusion in workplaces around the nation-would come to the fore only when activists entered the fray in the years following the statute's enactment. At one level, the book might be simply stating a truism known to lawyers and nonlawyers alike - that statutes are not self-executing without some further action. ${ }^{15}$ But I think that, given the weight which this framing device bears in the text, she means more than this. The book seems to rely on the distinction between one kind of equality that the statute confers, and another type of equality that only comes to the fore once ordinary people and activists - who tend to drive the story in much of social history-come into play.

In black politics, the analogue to the distinction that Johnson mobilized was Bayard Rustin's famous essay, "From Protest to Politics," which appeared not long before Johnson delivered his speech. Rustin divided the civil rights movement into its classical phase (1954-64), when African Americans pushed for the removal of formal barriers to equality, and its political phase, when they began to push for substantive equality in economic life, education, and other areas. ${ }^{16}$ Both Johnson and Rustin relied on the distinction between formal equality (removing explicit barriers to participation) and substantive equality (actual African American participation in the nation's institutions). In their telling, the issue of substantive equality emerges only when social movements try to put formal rights into practice. I'd like to suggest that the distinction isn't so neat.

In fact, the book's interpretation of the period before Title VII was enacted is somewhat conventional (unlike what it does with the statute's aftermath). In this telling, the rejection of a permanent federal FEPC in the late 1940s signaled the end of the road for nondiscrimination rights in the workplace until 1964. There was advocacy around these issues, to be sure-for instance, in state FEPCs, in the labor movement, and within the Truman administration. There was no real debate, however, about the legal contours of the right to nondiscriminatory employment until social movement activists renewed the fight during the 1960s (30, 38-44).

However, recent work in legal history calls this periodization into question. For instance, Sophia Lee has shown that the lawyers and activists within the NAACP's national office were steadily working their way to-

15. Indeed, NAACP labor activist Herbert Hill made this exact point in the aftermath of the statute's enactment: "Title VII not self-enforcing." Nancy MacLean, "Achieving the Promise of the Civil Rights Act: Herbert Hill and the NAACP's Fight for Jobs and Justice," Labor: Studies in Working-Class History of the Americas 3 (2006): 13, 14.

16. "From Protest to Politics: The Future of the Civil Rights Movement," in Time on Two Crosses: The Collected Writings of Bayard Rustin, ed. Devon W. Carbado and Donald Weise (San Francisco: Cleis Press, 2003), 116. Rustin's recent biographer notes that Johnson's Howard speech "framed civil rights in terms that Rustin himself might have crafted." John D'Emilio, Lost Prophet: The Life and Times of Bayard Rustin (New York: Free Press, 2003), 417. 
wards the issue of substantive equality as early as the 1950s, in little-known labor union litigation before the National Labor Relations Board. They took on, as well, another problem that is typically seen as not reemerging until the 1960s - the question of whether legal mandates reached putatively private conduct by discriminatory unions. Anthony Chen has done complimentary work in his recent article on opposition to state-level FEPCs, where opponents charged that nondiscrimination mandates would result in "quotas" that would guarantee minority inclusion in the workforce. In 1946, Republican Senator Robert Taft went so far as to propose a new federal FEPC that would have been empowered to grant relief that, under some circumstances, might fairly be read to include group-based representation in the workplace. From the moment the FEPCs were proposed, they brought to the table the question of what form of "equality" they were supposed to foster. Indeed, the debate goes even further back to the New Deal era, when the black boycott movements for jobs in African American neighborhoods and the movement for racial equality within the government contracting workforce demanded, and received, mandates for the inclusion of specific numbers of African Americans in the workplace. ${ }^{17}$

I'd like to suggest that Rustin, and Johnson, exhibited a degree of historical blindness when they argued that the previous movement had focused solely on formal equality, while substantive equality was the work of the future. As a veteran of the left branch of civil rights politics, Rustin must have known this to be untrue. There is a good chance that Johnson and his aides did also. Indeed, Richard Goodwin, the White House aide who helped draft Johnson's speech, was a lawyer and a former law clerk to Justice Felix Frankfurter, who himself had been a proto-realist figure in his youth. By 1965, however, Rustin was shedding his own vagabond past and moving to a more respectable place within the movement, while Johnson and his advisors were trying to convince the American public that the struggle for racial equality was not over. Each had powerful incentives to

17. Lee, "Hotspots in a Cold War," 328, 366-68; Anthony Chen, “"The Hitlerian Rule of Quotas': Racial Conservatism and the Politics of Fair Employment Legislation in New York State, 1941-1945," Journal of American History 92 (2006): 1238; David Engstrom, "The Taft Proposal of 1946”; Michele F. Pacifico, “'Don't Buy Where You Can't Work': The New Negro Alliance of Washington," Washington History 6 (1994): 67, 79-80; Robert Weaver, "An Experiment in Negro Labor," Opportunity 14 (October 1936): 295; Marc W. Kruman, "Quotas for Blacks: The Public Works Administration and the Black Construction Worker," Labor History 16 (1975): 37, 44; Paul Moreno, From Direct Action to Affirmative Action: Fair Employment Law and Policy in America, 1933-1972 (Baton Rouge: LSU Press, 1997), 30-65. Taft's proposal was inartfully drafted, but group representation is one fair reading of its language. A number of observers within the NAACP and the labor movement read it as contemplating group-based relief and were uneasy with it for that reason. Engstrom, "Lost Origins of American Fair Employment Law," 151-53. 
suppress some of the contingency and malleability in the history of civil rights politics up to 1964 , and at least some of that suppression has made it into our own histories of the movement. ${ }^{18}$

In addition, I'd like to note that in Nancy's narrative, the debate over substantive equality emerges "away" from law, as social movement activists try to transform the formal rights encompassed within the statute into practical inclusion in the workforce. For a book about the social consequences that attach to a particular legal enactment, there is only a limited discussion of the enactment itself and the complex history and debates that preceded it. In Freedom is Not Enough, the engine that moves the story along is encompassed in the words and deeds of the job seekers, workers and activists who struggle with the statutory mandate of formal equality. But it's not at all clear that the statute itself grants only formal rights-or at least, that the issue of substantive equality emerges only outside of the formal bounds of law. Just to take one example, the legal scholar Owen Fiss spent the early part of his career showing that the equality principle encompassed in any nondiscrimination mandate actually consists of two principles, not one: (1) removal of formal barriers to participation, and (2) actual inclusion in American institutions. ${ }^{19}$ Indeed, as early as 1971, Fiss argued that the employment law regime that emerged in the aftermath of Title VII was amenable to both interpretations. ${ }^{20}$ So it may very well be the case that the "freedom" that the statute conferred may have been "enough" to at least raise the question of equality of inclusion, and was not simply the formal mandate that it appears to be in the book.

There are large political stakes behind this move to define freedom expansively. For instance, it has become quite common for political conservatives to argue that mainstream American understandings of workplace justice at the time of the 1964 Act only encompassed formal equality. In this narrative, the issue of race-conscious inclusion did not emerge in the modern era until left-liberal activists distorted the original meaning of the mid-1960s moment. ${ }^{21}$ Even those scholars who try to move beyond the polemics and normative judgments often assume that the commonsense

18. Robert Dallek, Flawed Giant: Lyndon Johnson and His Times, 1961-1973 (New York: Oxford University Press, 1998), 222; D’Emilio, Lost Prophet, 393-439.

19. See, for example, Owen Fiss, "Groups and the Equal Protection Clause," Philosophy and Public Affairs 5 (1976): 107; Owen Fiss, "A Theory of Fair Employment Laws," University of Chicago Law Review 38 (1971): 235; Owen Fiss, "Racial Imbalance in the Public Schools: The Constitutional Concepts," Harvard Law Review 78 (1965): 564.

20. Fiss, "A Theory of Fair Employment Laws."

21. See, for example, Stephan and Abigail Thernstrom, America in Black and White: One Nation, Indivisible (New York: Simon and Schuster, 1997), 423-61; Paul Moreno, From Direct Action to Affirmative Action, 266, 279. 
meaning of discrimination before the mid-1960s only encompassed formal equality - when that assumption seemed like anything but common sense to civil rights advocates and their opponents as they debated the meaning of workplace equality in the decades preceding Title VII. ${ }^{22}$ This makes it all the more important not to concede this ground without defining precisely what we mean when we talk about the ideas of "freedom" that were debated in the civil rights era and eventually enacted into law.

There is something similar at work in how Nancy treats those who come to oppose substantive equality - certain Jewish activists and intellectuals, and many political conservatives. I don't mean to collapse the subtlety and contextualism with which the book treats each of these sometimes-related groups of people who balked at race consciousness. Moreover, no one would equate the set of motives and impulses that led some Jewish activists to balk at race-conscious faculty hiring in higher education with those that led conservatives to come to oppose affirmative action writ large. But I would like to suggest some commonalities in the way the book treats these two groups that relate to the way it sets up the progression from formal to substantive equality.

In framing the stories of the Jewish activists and political conservatives, Freedom is Not Enough downplays the longer history of the contested meaning of workplace equality in American life. For instance, the book refers to Jewish intellectuals' retreat from affirmative action as a "fall back on identity politics" (186). It refers to conservatives' replacement of their former anti-civil rights rhetoric of property rights with their new rhetoric of colorblindness as a "ploy" (238). Of course, one cannot ignore Jewish activists' realization that the interests encompassed in their group identity might differ from those of black Americans, or conservatives' instrumental need to replace their previous anti-civil rights rhetoric with an updated version. Indeed, with regard to certain figures in the story, namely Patrick Buchanan and James Kilpatrick, Nancy's argument seems convincing to me. Nonetheless, it is also true that-as I have noted in my discussion above - advocates of formal equality (as did those of substantive equality) drew on longer and more respectable currents of American ideals than those that emerged in the 1970s. For the three decades preceding the civil rights measures of the mid-1960s, both forms of equality percolated within civil rights discourse, and the enactment of Title VII did not resolve the debate between them.

This is true even within African American politics. As far back as the

22. John David Skrentny, "Introduction," in Color Lines: Affirmative Action, Immigration, and Civil Rights Options for America (Chicago: University of Chicago Press, 2001), 1-6; John David Skrentny, The Ironies of Affirmative Action: Politics, Culture, and Justice in America (Chicago: University of Chicago Press, 1996), 7, 28-29. 
New Deal, black activists still couched their pleas for nondiscrimination as calls for the inclusion of "qualified" Negroes in the job pool. For instance, Chicago lawyer Earl Dickerson argued, in the midst of a campaign for political office in the late 1930s, that "jobs on public utilities have been systematically denied qualified Negro workers." 23 I've always wondered-why did black activists so often append the word "qualified" in a world of fairly explicit color bars to employment? Why not simply demand that black workers be hired, and leave it at that? I believe that it is because the language of formal nondiscrimination against qualified black applicants - i.e., that if the barriers to the hiring of qualified Negroes were removed, that would be enough — was already part of the rhetorical toolkit of black activists as early as the 1930s. In fact, fierce debates broke out among African Americans themselves during the boycott movements of that decade over calls for inclusion of specific numbers of black workers to be hired in businesses located in African American communities, as they would again during the next decade over the same issue when civil rights advocates began the push for a permanent FEPC and the integration of the labor force. ${ }^{24}$ As Mark Tushnet has argued, "at nearly every moment, there were articulate advocates for nondiscrimination and for proportionality" by race in the workplace. ${ }^{25}$ When Jewish intellectuals and conservatives drew on the rhetoric of formal equality in the 1970s, they mobilized language and ideas that could be found in many unexpected places in the fabric of American life.

Finally, I would like to turn to Nancy's chapter on women activists and "Jane Crow"- the exclusion of women from certain lines of male-identified work. The term "Jane Crow" comes from Pauli Murray, the well-known civil rights lawyer, feminist, and activist who is the central African American participant in the story chronicled in the book. This chapter shows women activists, including some black women, eventually coalescing around a program of nondiscrimination in access to jobs, rather than a program that preserved protected spaces in the workforce for women (117-54). One wonders, however, how representative Pauli Murray is of the general attitudes of black women activists toward that dilemma.

In some ways, Murray must be unrepresentative of the general run of black women activists of her place and time. Murray broke with what is still a central ideological imperative within respectable black life in that she

23. "Dickerson Tells Second Ward Aims," Daily Record (Chicago), February 11, 1939, box 1, book 1, Earl Dickerson papers, Chicago Historical Society.

24. Pacifico, "Don't Buy Where You Can't Work," 79-80; Kruman, "Quotas for Blacks" 44; Moreno, From Direct Action to Affirmative Action, 35-39, 95-100.

25. Mark Tushnet, "Book Review-Paul Moreno, From Direct Action to Affirmative Action," American Journal of Legal History 42 (1998): 337, 338. 
was married for only the briefest of moments in her youth and never had children. She had a complex and dissenting sexual identity that scholars are still trying to sort out. ${ }^{26}$ Moreover, she spent much of her life clashing with other black people, from her rejection as a plaintiff in an NAACP suit in the 1930s to her disputes with other students at Howard Law School over gender discrimination to her disillusionment with what became a central preoccupation of African Americans-Kwame Nkrumah's experiment in African independence in Ghana. ${ }^{27}$

To put Murray into context, it may be useful to contrast her with another black woman, albeit about a decade older then she-Philadelphia lawyer Sadie Alexander. Like Murray, Alexander was an elite lawyer within the black bar; she was a graduate of the University of Pennsylvania Law School. Like Murray, she was a central figure in post-World War II civil rights politics. Alexander was one of only two black members of Harry Truman's President's Committee on Civil Rights, served as chair of the Philadelphia Commission on Human Relations, was on the board of the ACLU, and marched from Selma to Montgomery with Martin Luther King, Jr. Unlike Murray, however, Alexander was married for most of her adult life - to another lawyer, Raymond Pace Alexander, and raised children while embarking on her legal career. She was also heir to the politics of respectability that Evelyn Higginbotham has argued was the mainstream political discourse among middle-class black women in the early part of the twentieth century. ${ }^{28}$

Sadie Alexander spent the latter part of her career rejecting Murray's idea of Jane Crow. She resisted the analogy between race and sex discrimination, and focused most of her activism on race alone. She professed to disdain the cause of second-wave feminism to which Murray allied herself. Most importantly, she defended gender-segmented workplaces for women, even

26. See, for example, Doreen Marie Drury, "Experimentation on the Male Side: Race, Class, Gender, and Sexuality in Pauli Murray's Quest for Love and Identity, 1910-1960" (Ph.D. diss., Boston College, 2000); Glenda Gilmore, Defying Dixie: The Radical Roots of Civil Rights, 1919-1950 (New York: W.W. Norton \& Co., 2008), 288, 324-26; Rosalind Rosenberg, "The Conjunction of Race and Gender," Journal of Women's History 14 (2002): 68, 69-70.

27. Pauli Murray, Song in a Weary Throat: An American Pilgrimage (New York: Harper \& Row, 1987), 126-28, 214-19, 343-44; Gilmore, Defying Dixie, 264-90; Kevin K. Gaines, African Americans in Ghana: Black Expatriates and the Civil Rights Era (Chapel Hill: University of North Carolina Press, 2007), 110-35.

28. Kenneth W. Mack, "A Social History of Everyday Practice: Sadie T.M. Alexander and the Incorporation of Black Women into the American Legal Profession, 1925-60," Cornell Law Review 87 (2002): 1405. On the politics of respectability, see Evelyn Brooks Higginbotham, Righteous Discontent: The Women's Movement in the Black Baptist Church, 1880-1920 (Cambridge: Harvard University Press, 1993), 185-229. 
though her rich and active public life was, in its own way, an eloquent attack on gender segmentation in the workplace and elsewhere. Alexander professed that she did not want to engage in male-identified tasks in the legal profession, such as criminal defense work. Instead, she made her career out of domestic relations, probate, divorce, and other practice areas identified with women. She reportedly turned down an offer of a judgeship so that it would be later offered to her husband. To the end of her life, she defended the primary responsibility of wives to be caretakers of the home and that of husbands to be the primary breadwinners, presumably occupying higher-prestige jobs than their wives. ${ }^{29}$

Why did Alexander do these things? What made her so different than Murray? In part, the explanation lies in the tradition of middle-class black respectability that she inherited from her family and that Murray was born into but rejected. Yet, Alexander was also different than Murray because she was married with children while establishing a successful career. Her professional correspondence is filled with references to the everyday tasks of caring for her children and the necessity of leaving work early, missing meetings, and preparing meals for her family. References to family and child care only rarely appear in the writing of her husband. Certainly one key to Alexander's attitude toward Jane Crow lay in her marriage, which created a gender-segmented and protected space in the law firm founded by her husband. That segmentation allowed her professional career to flourish, while she cared for her family and conceded the high-prestige courtroom work to men.

Although the comparison, of course, is inexact, Alexander provides a contrast with Murray within black women's politics. She was in a different position of social and economic power than many of the relatively independent white women activists who populate Nancy's chapter on Jane Crow. This raises the question of whether Alexander's social, material, and cultural circumstances were closer to those of her fellow black women lawyers and activists than those of the iconoclastic, and unattached, Murray.

Freedom is Not Enough is all the more brilliant for raising questions such as these, and perhaps leaving them for future scholars to answer. This is a book that will define and challenge the paradigms, controversies, and debates that will structure the future direction of this field of scholarship. I look forward to reading what others will now do and write in the ground that Nancy's book has plowed up.

29. Mack, "Social History of Everyday Practice," 1432 n. 155, 1443 n. 216, 1470-71; Curtis Carson, interview by Kenneth W. Mack, Philadelphia, Pa., June 11, 1999. 